\title{
Hepatitis C-vírus- (HCV-) infekció és malignus lymphomák: az ellátás szempontjai egy HCV-pozitív, marginalis zóna lymphomás beteg esete kapcsán
}

\author{
Folhoffer Anikón ${ }^{1}$, Tárkányi Ilona ${ }^{1}$, Németh Dániel ${ }^{1}$, Csernus Balázs ${ }^{2}$, Rajnai Hajnalka ${ }^{2}$, \\ Matolcsy András ${ }^{2}$, Kaposi Novák Pál ${ }^{3}$, Abonyi Margit ${ }^{1 \dagger}$, Tóth Tamás ${ }^{1}$, Szalay Ferenc ${ }^{1}$, \\ Demeter Judit ${ }^{1}$
}

\author{
${ }^{1}$ Semmelweis Egyetem, Belgyógyászati és Onkológiai Klinika, Budapest \\ ${ }^{2}$ Semmelweis Egyetem, I. sz. Patológiai és Kísérleti Rákkutató Intézet, Budapest \\ ${ }^{3}$ Semmelweis Egyetem Orvosi Képalkotó Klinika, Budapest
}

\begin{abstract}
Bevezetés: A hepatitis C-vírus (HCV) krónikus májgyulladáshoz, májcirrhosishoz, májrákhoz vezethet. A Flaviviridae csoportba tartozó RNS vírus nemcsak hepatotrop, de lymphotrop tulajdonsággal is rendelkezik. Számos extrahepatikus manifesztációja között jelentős a lymphoproliferatív eltérés. A főként B-sejtes betegségek közül leggyakoribb az alacsony malignitású marginalis zóna lymphoma, a diffúz nagy B-sejtes lymphoma, valamint a follicularis lymphoma. Beteg: A hypertoniás, visszérműtéten átesett 54 éves férfi beteg thrombopeniájának, indirekt, Coombs-pozitív hyperbilirubunaemiájának és hepatosplenomegaliájának hátterében HCV-infekció talaján kialakult Child B stádiumú májcirrhosis igazolódott. Az inhomogén szerkezetû, megnagyobbodott, lobulált felszínủ májban körülírt eltérés nem látszott. A portalis keringés megtartott volt. A máj fokozott keménysége (26 kPa, IQR/med. 18\%) F4 cirrhosisra utalt. A homogén szerkezetú lépet jelentősen nagyobbnak $(20 \times 9 \mathrm{~cm})$ mértük. A perifériás vérkenet alapján lymphoma gyanúja merült fel, amit a crista-biopsia eredménye megerősített, CD5/CD10-negatív marginális zóna lymphomát (MZL) diagnosztizáltunk. A fenti májbetegségnek és a HCV 1 b genotípusnak megfelelően, sofosbuvir/ledipasvir direkt antivirális kezelést indítottunk. A 12 hetes kezelés tartós vírusmentességet eredményezett. Mind a májbetegség, mind a lymphoma tünetei mérséklődtek, a beteg testsúlya nőtt, fáradékonysága megszűnt. Megbeszélés: Az irodalomból is ismert, hogy a krónikus C hepatitisben a B-sejtes lymphomák előfordulása gyakoribb. Az antiviralis kezelés hatására lymphoma javulását is leírták, esetünkben a társuló immunhaemolysis mértékének csökkenését észleltük. Lymphomaspecifikus kezelés jelenleg nem szükséges, a beteg tünetmentes és stabil, progresszió esetén rituximab monoterápia jön szóba. Következtetés: A fenti eset példa a HCV-pozitív betegekben előforduló B-sejtes lymphomára. Bár az irodalomból ismert, hogy a hepatitis C-vírus eradikációjával a B-sejtes non-Hodgkin-lymphoma regrediálhat, esetünkben az eddig eltelt vírusmentes időszakban ezt még nem észleltük, igaz, hogy progressziót sem.
\end{abstract}

Kulcsszavak: lymphoma, hepatitis C, kezelés

\section{Hepatitis $\mathrm{C}$ virus (HCV) infection and malignant lymphomas: aspects of care in a $\mathrm{HCV}$-positive patient's case with marginal zone lymphoma}

\footnotetext{
Introduction: Hepatitis C virus (HCV) may lead to chronic hepatitis, liver cirrhosis and cancer. HCV has not only hepatotropic, but also lymphotropic properties. Among several extrahepatic manifestations lymphoproliferative disorders are the most important. $\mathrm{HCV}$-associated lymphoma is mainly $\mathrm{B}$-cell histological type, most commonly low-grade mar-
}

\footnotetext{
@ Levelezési cím: Dr. Folhoffer Anikó, Semmelweis Egyetem, Belgyógyászati és Onkológiai Klinika, 1083 Budapest, Korányi S. u. 2/A, Tel.: +36-20-9949-678, E-mail: folhoffer@gmail.com
} 
ginal zone lymphoma, diffuse large B-cell lymphoma, and follicular lymphoma. Patient: A 54-year-old male patient with hypertension and varicectomy in past history, had thrombopenia, indirect Coombs-positive hyperbilirubinaemia and hepatosplenomegaly due to Child B stage hepatitis $\mathrm{C}$ viral liver cirrhosis. There was no focal lesion in his enlarged, inhomogeneous liver. Portal vein flow was retained. Increased liver stiffness (26 kPa, IQR/med. 18\%) referred to F4 cirrhosis. His spleen was significantly enlarged $(20 \times 9 \mathrm{~cm}$ in diameter). Based on the peripheral blood smear, the suspicion of lymphoma arose and was confirmed by bone marrow biopsy. CD5/CD10-negative marginal zone lymphoma was diagnosed. According to the liver cirrhosis and the HCV genotype 1b, sofosbuvir/ledipasvir direct antiviral treatment was initiated. Sustained viral response was achieved at week 12. Both liver disease and lymphoma symptoms were reduced, patient's weight increased, fatigue ceased. Discussion: As known from the literature incidence of B-cell lymphoma is higher in chronic hepatitis $\mathrm{C}$ and antiviral treatment has been reported to improve lymphoma, also. In our case the decrease in the severity of immunhemolysis was observed. Lymphoma specific treatment is not necessary now, the patient is non-symptomatic and stable, but in case of hematological progression rituximab monotherapy will be suggested. Conclusion: Our case is an example of B-cell lymphoma in HCV-positive patients. Although it is known in the literature that eradication of HCV virus may lead to regression of B-cell non-Hodgkin's lymphoma, we have not seen improvement so far, in the virus-free period, however, there was no progression, either.

Keywords: lymphoma, hepatitis C, treatment

(Beérkezett: 2019. szeptember 16.; elfogadva: 2019. november 10.)

\section{Rövidítések}

AID = activation-induced cytidine deaminase ALP = alkaline phosphatase; $\mathrm{BAFF}=\mathrm{B}$-cell activating factor of tumor necrosis factor family; $\mathrm{CD}=$ cluster of differentiation; $\mathrm{DAA}=$ directacting antiviral agent; DLBCL = diffuse large B-cell lymphoma; $\mathrm{EBV}=$ Ebstein-Bar-vírus; GGT = gamma glutamyl transferase; GLE/PIB = glecaprevir/pibrentasvir; GZR/EBR = grazoprevir/elbasvir; HCV = hepatitis C-vírus; HHV8 = human herpesvírus 8 ; HTLV1 = human $\mathrm{T}$ lymphocyte vírus $1 ; \operatorname{IgM}=\mathrm{im}$ munoglobulin M; IPI = international prognostic index; LDH = lactate dehidrogenase; MALT $=$ mucosa-associated lymph tissue; $\mathrm{MC}=$ mixed cryoglobulinaemia; $\mathrm{miR} 29 \mathrm{a}=$ microRNA 29a; NS3, NS4, SS5 stb. = non-structural protein; OBV $/ \mathrm{PTV}-\mathrm{r} /$ $\mathrm{DSV}=$ ombitasvir $/$ paritaprevir $/$ ritonavir $/$ dasabuvir; ORF = open reading frame; $\mathrm{PCR}=$ polymerase chain reaction; $\mathrm{RF}=$ rheuma factor; RNS = ribonucleic acid; ROS $=$ reactive oxigen species; SOF/VEL = sofosbuvir/velpatasvir; SOL/VEL/VOX = sofosbuvir/velpatasvir/voxilaprevir; $\mathrm{TGFb}=$ transforming growth factor beta; UTR = untranslated region

\section{A HCV előfordulása, kezelése}

Napjainkban is a hepatitis C-vírus okozza a krónikus májbetegségek jelentős részét, amelyek végstádiumában májzsugor, illetve rosszindulatú májdaganat alakulhat ki [1]. A hepatitis C-vírus az esetek 20-30\%-ában akut hepatitiszszindrómát okozhat, ám 75-85\%-ban krónikussá válik [2, 3]. A Flaviviridae csoportba tartozó, kisméretü, egyszálú RNS vírusról azonban mára pontosan tudjuk, hogy nemcsak hepatotrop, de lymphotrop tulajdonsággal is rendelkezik [4-5]. Epidemiológiai vizsgálatok szerint a B-sejtes lymphomák gyakorisága nagyobb a hepatitis C-pozitív krónikus májbetegekben, nemcsak a magas prevalenciájú régiókban $[7,8]$, hanem általánosságban, a teljes populációban is [9-12]. A HCV extrahepatikus manifesztációi között szerepelnek a kevert cryoglobulinaemiák, a porphyria cutanea tarda, a lichen planus, neuropathiák, thyreopathiák, idiopathiás tüdőfibrosis, diabetes mellitus, polyarthritis, szexuális dysfunctio, cardiopathia, atherosclerosis és pszichiátriai eltérések.

Becsült adatok alapján kb. 71-170 millió a krónikus hepatitis C-vírus-fertőzött betegek száma a világon [13].

$\mathrm{Az}$ antivirális kezeléssel elsődleges cél a tartós vírusválasz elérése. Ezzel a májbetegség progressziója megállítható, a későbbi relapszus veszélye minimálisra csökken, illetve javulás várható, mind a laboradatok, mind a nekroinflammatorikus folyamatok tekintetében. A vírus eliminációja nemcsak a májbetegség tüneteit javítja, de lényeges, hogy a HCV extrahepaticus megjelenését is visszaszorítja [14].

Magyarországon 50000-re becsülhető a fertőzőképes HCV-RNS-pozitív egyének száma $[15,16]$. A vírust néhány évvel ezelőtt még leggyakrabban a korábban nem szürt vérkészítményekkel, egészségügyi beavatkozások során, illetve szexuális úton szerezték a betegek [17]. Mára azonban nem elhanyagolható, sőt egyre inkább növekvő számú az intravénás kábítószerek használata során szerzett HCV-infekció. A vérkészítmények szürésével 1993 óta minimálisra csökkent az orvosi beavatkozások során iatrogén módon átvitt fertőzési mód.

A HCV elleni küzdelemben az utóbbi években óriási fejlődés tapasztalható. A ribavirin előtti $10 \%$-os, majd az interferon érában látott 30-55\%-os gyógyulási arány jelentős mértékben javult, mára elérte a 95\%-ot (1. ábra).

A vírus genomjának a feltérképezésével és ezzel együtt a vírus bejutásának, illetve sejten belüli életciklusának megismerésével lehetőség nyílt a mai korszerü, direkt antivirális gyógyszerek használatára [18-19] (2. ábra). Segítségükkel a legtöbb, nehezen kezelhető betegcsoportban is $90 \%$ fölé emelkedett a tartósan vírusmentessé tehető bete- 


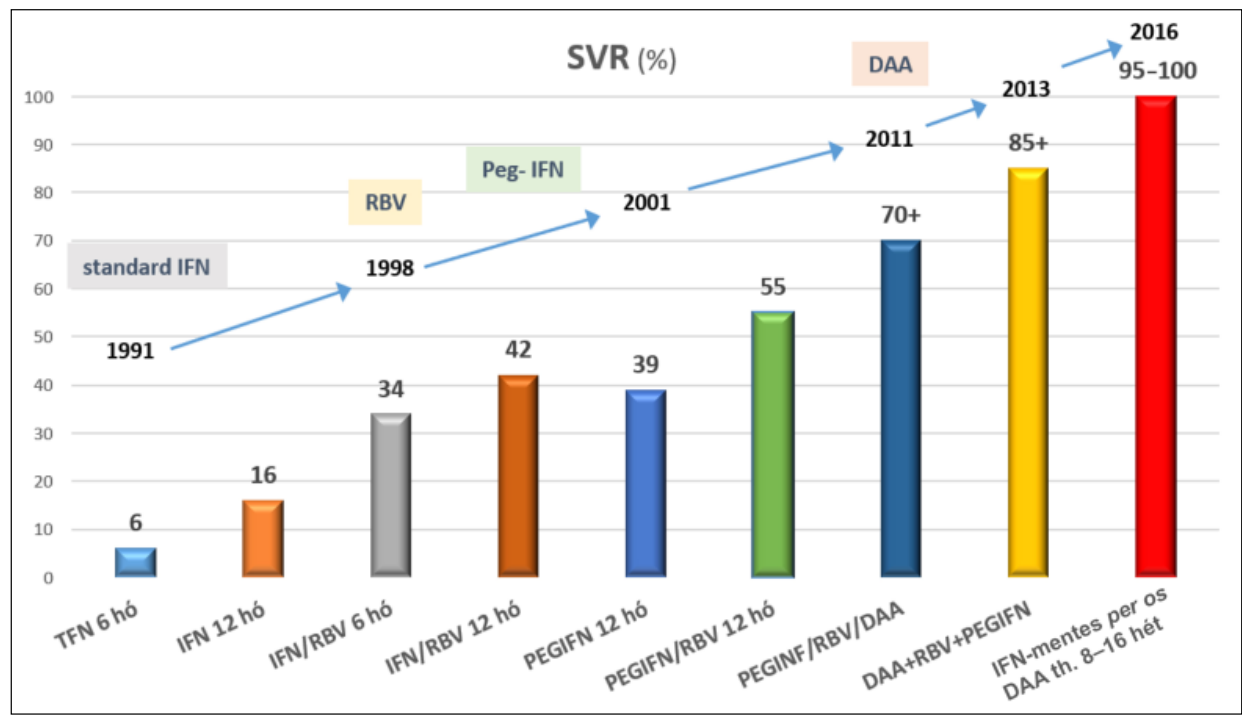

1. ábra. A hepatitis C-vírus kezelésének evolúciója. SVR: sustained viral response - tartós virológiai válasz, IFN: interferon, RV: ribavirin, DAA: direkt antivirális szer

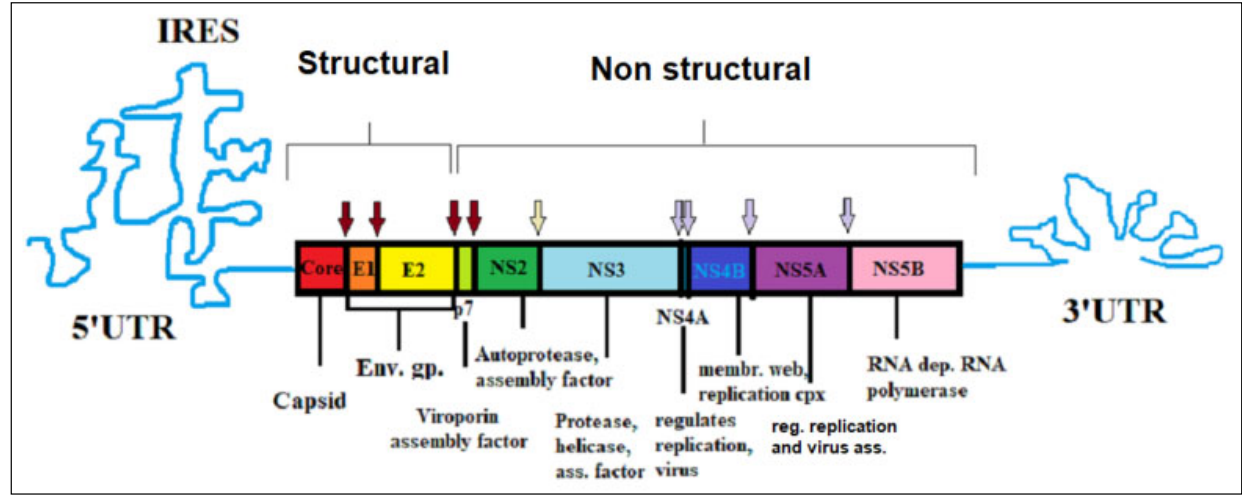

2. ábra. A hepatitis C-vírus genomszerkezete. IRES, UTR, E envelope, NS non structural - nem strukturális. (Abdel-Hakeem MS, Shoukry NH [20] - módosított ábra, a szerzők engedélyével)

gek aránya [21]. Ezáltal elérkeztünk arra a pontra, hogy a WHO célul tüzhette ki a hepatitis C-vírus globális visszaszorítását [22]. Az új fertőzések számának 90\%-os csökkenésével a betegséghez társuló halálozás $60 \%$-os csökkenése várható 2030-ig. A most ismert betegek sikeres kezelését követően új feladat az újabb és újabb HCV-pozitív betegek felkeresése, szürése és gyógyítása. A hepatitis Cvírus genotípus megoszlásában is változás figyelhető meg. A korábbi terápiák tekintetében nehezen kezelhető, hazánkban leggyakoribb 1-es (azon belül is föként 1b) genotípus [23] a direkt antivirális szerek idejében előnnyé vált. A kompenzált májbetegségben első vonalban alkalmazott paritaprevir/ritonavir/ombitasvir + dasabuvir hatóanyagtartalmú kezelés szempontjából ez a legkedvezőbb alcsoport. Ebben a terápiában több támadáspontot is célba véve egy nem strukturális (NS) 3/4A-gátló, egy NS5A- és egy NS5B-gátlót alkalmazunk kombinációban. A ritonavir a proteázgátló hatását potencírozza. A változó vírusátviteli mód, az intravénás droghasználók, a homoszexuális férfiak („men who have sex with men”) és az országok közti migráció terjedésével viszont a nálunk korábban rit- kának számító 3-as, 4-es, illetve egyéb genotípus is egyre gyakoribbá válik. Emiatt külön jelentőséggel bírnak a legújabban megjelent pangenotipikus, vagyis minden genotípusra hatékony szerek. A 3. ábrán látható a hepatitis Cvírus életciklusa és a direkt antivirális szerek célpontjai [24].

Mára Magyarországon is lehetővé vált, hogy minden újonnan felfedezett beteget a korszerü direkt antiviralis kezelések valamelyikével, interferon nélkül gyógyíthassunk, 8-12 hetes kezelési periódusokkal. A per os adható szerek mellékhatást alig okoznak, miközben $90 \%$ felett érhető el velük tartós vírusmentesség. A kezelések során érdemi mellékhatásra csupán a kiegészítő ribavirinkezelés miatt kell számítani.

Kompenzált májbetegekben tehát a paritaprevir/ritonavir/ombitasvir + dasabuvir hatóanyag-tartalmú antivirális kezelés ajánlott, cirrhosisban ribavirinnel kiegészítve. Dekompenzált májbetegségben pedig ma még elsőként, a nálunk leggyakoribb 1b genotípusban szintén jól használható ledipasvir/sofosbuvir-kezelés javasolt (1, 4, 5 és 6-os genotípusra törzskönyvezve). A korábbi kezelések 


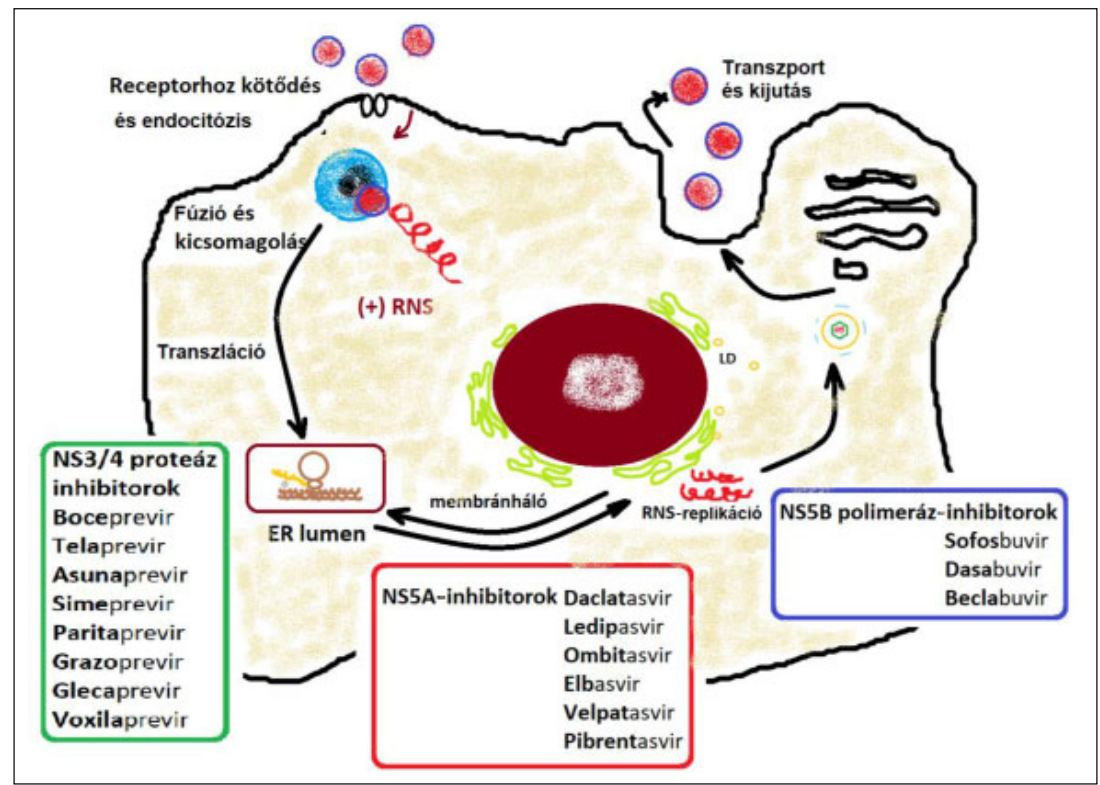

3. ábra. A hepatitis C-vírus életciklusa és a direkt antivirális szerek célpontjai.

(Manns MP, et al. [24] alapján, módosítva)

után visszaeső betegek számára, illetve dekompenzált májcirrhosisban, ribavirinnel kiegészítve. Ennek az az oka, hogy elörehaladott májbetegségben, Child B és C cirrhosisban a proteázgátlók ellenjavalltak, mert azok döntően a májban metabolizálódnak, és az ilyen betegekben a proteázgátlók vérszintje akár tízszeresére is nőhet [25]. Vesebetegek esetében $30 \mathrm{ml} /$ perc GFR alatt viszont a sofosbuvir nem adható, mert annak metabolitja a vesefunkció súlyos beszúkülése esetén a terápiás szintet 1020-szoros mértékben meghaladhatja.

Tehát lényeges előrelépés, hogy a HCV-ellenes antivirális kezelés mára igencsak leegyszerüsödött, és a hepatitis $\mathrm{C}$-vírus gyógyítható betegséggé vált. A terápiában a legnagyobb odafigyelést az új antivirális szerek használatában a gyógyszer-interakciók követése kívánja. Ebben több online adatbázis, például a hepdrug-interaction.com [26] áll segítségünkre.

A gyógyszerkutatás napjainkban a minden genotípusra ható, minél kevesebb gyógyszer-interakciót okozó, hasonlóan jó mellékhatás-profilú és biztonságosságú, rövid idejü kezelést lehetővé tevő szerek kifejlesztésére irányul. Nehézséget jelent, hogy a kezelés alatt a gyors vírusreplikáció során a vírus aminosav-szekvenciájában direkt hatású antivirális gyógyszer (DAA) rezisztens mutációk jöhetnek létre [27, 28]. A rezisztencia-asszociált variánsok, szubsztitúciók megnehezítik a vírusellenes kezelést. Emiatt több különböző támadáspontú gyógyszer kombinációjára, a különböző nem strukturális fehérjékre ható szerek együttes alkalmazására van szükség.

Mára a legnehezebben kezelhető betegcsoportba a dekompenzált májcirrhosisban szenvedő, a HCV 3-as genotípussal fertőzött, illetve a korábbi kezelésekre (első DAA-kezelésre) nem gyógyulók tartoznak. A legújabb gyógyszerfejlesztések ezeknek a betegcsoportoknak a gyógyítására irányulnak.
A fent említett kezelésekre nem reagáló, igen ritka esetekben van szükség az újabb gyógyszerekre. Második generációs proteázgátlót és NS5A-gátlót tartalmazó és grade IV. vesebetegségben is alkalmazható az elbasvir/ grazoprevir-terápia (lényeges a genotípus ismerete). Genotípusra és fibrosisstádiumra való tekintet nélkül kitünő eredményekkel adható a sofosbuvir/velpatasvir, 12 hetes kezelési idővel, ribavirin nélkül. Az eddig felsorolt szerekre nem gyógyult betegek számára pedig még két újabb direkt antivirális kombináció, a sofosbuvir/velpatasvir/voxilaprevir és a glecaprevir/pibrentasvir áll rendelkezésre, hazánkban jelenleg egyedi méltányosság útján.

\section{HCV és lymphoma együttes előfordulása}

A hepatitis C-vírus számos extrahepatikus manifesztációja közül az egyik leggyakoribb a nyirokrendszert érinti, lymphoproliferatív betegségeket okozva $[4,29,30]$. A fóként B-sejtes eltérések közül leggyakoribbak az alacsony malignitású marginális zóna lymphomák (MZL), azok közül is a splenicus eredetúek és a diffúz nagy B-sejtes lymphomák (DLBCL), ezt követik a follicularis lymphomák (FL) [31, 32]. Mindezek azokban a betegekben alakulnak ki, akiknek a krónikus hepatitis C-vírus-fertőzése több mint 13-15 éve áll fenn.

A hepatitis C-vírushoz kapcsolódó indolens B-sejtes lymphomák gyakran extranodalisan jelennek meg, a lépben, nyálmirigyekben, ahol a vírus szaporodni képes [33]. A HCV-hez társult DLBCL sokszor a lépet, a májat, a gyomrot érinti, és a nemzetközi pontrendszerben (IPI) magas értéket ér el, nagy kockázatú betegségcsoportba tartozik, ami részben az emelkedett LDH-nak köszönhető [34]. A HCV-hez asszociált DLBCL két formája közül az 
egyikben csak a nagy B-sejtek vannak: de novo diffúz nagy B-sejtes lymphoma (DLBCL), míg a másikban ezekhez kis B-sejtes infiltráció társul. Ez utóbbi nagy valószínűséggel a köpenysejtes lymphoma transzformációjával alakul ki. A transzformálódott forma HCV-pozitív betegekben szignifikánsan gyakrabban fordul elő (32 vs. 6\%), a follicularis lymphoma megjelenését mindezeknél ritkábban írták le [38].

\section{$H C V$-infekció és B-sejt transzformáció}

Az utóbbi évtizedekben két infekció által vezérelt lymphocyta-transzformációs modell vált ismertté. Az egyik szerint a lymphotrop vírusok (EBV, HHV8 és HTLV1) az expresszálódó vírus onkogéneken keresztül direct lymphocyta-transzformációhoz vezetnek [35]. A másik modellben egy indirekt mechanizmus végül clonalis expanziót eredményez. Ez utóbbiak jól ismert példája a Helicobacter pylori-asszociált MALT lymphoma [34]. Egyre újabb és újabb eredmények utalnak arra, hogy a HCV-hez kapcsolt lymphomagenesisben számos transzformációs mechanizmus vesz részt.

Ezeket a folyamatokat Couronné és mtsai részletesen ismertetik cikkükben [4]. Ismert tény, hogy a kevert cryoglobulinaemia (MC) az esetek több mint 90\%-ában hepatitis C-vírushoz társul [37, 38]. Leggyakoribb a monoclonalis IgM cryoglobulinaemia, több-kevesebb vasculitises tünettel. A kevert cryoglobulinaemiás betegek 8-10\%-ában pedig később lymphoproliferatív kórkép alakul ki, míg a non-Hodgkin-lymphomás betegek között a cryoglobulinaemia előfordulása 35-ször gyakoribb. Tehát a kevert cryoglobulinaemia klinikailag egyfajta „jóindulatú” prae-lymphomatosus állapotnak tekintheto", melyben a csontvelő és a máj B-sejtjei indolens nonHodgkin-lymphoma képére emlékeztetnek. A HCV-hez kapcsolódó kevert cryoglobulinaemia IgM rheumatoid factor-aktivitást mutat, és részben autoreaktív az antiHCV IgG-antitestekkel szemben. Ez felveti annak lehetőségét, hogy az MC IgM RF keresztreakciója jön létre a vírusasszociált epitóp és az IgG autoantigén között, bár az RF B-sejtreceptor (BCR) IgM vagy a serum RF IgM és a $\mathrm{HCV}$-antigének közt ilyen keresztreaktivitás nem igazolódott eddig. További érdekesség, hogy a HCV-pozitív lymphomás betegek B-sejt receptora nem képes HCV-antigénekhez kötődni. Az irodalmi adatok alapján úgy tünik, hogy a HCV-hez társult lymphoma kialakulásában leginkább valamiféle autoimmun mechanizmus játszhat szerepet.

Számos tanulmány utal arra, hogy a HCV envelope glycoprotein E2-nek nagy szerepe lehet az indirekt transzformációban, az E2-CD81-kötődés kapcsán (a CD81/ CD19/CD21) kostimulációs komplex segítségével. A HCV E2-CD81-receptorhoz való kötődése az immunglobulin gén locus somaticus hypermutatióját is indukálja az AID (aktiváció indukálta deamináz) aktiválása útján, és ez a folyamat független a hepatitis C-vírusreplikációtól, illetve a B-sejtek direkt HCV-infekciójától. Ez a folyamat játszódik le egyébként maláriafertőzésben is.

Hasonlóképpen, a citokinek és mikrokörnyezetük is lényeges szerepet játszanak a lymphomagenesisben, még-

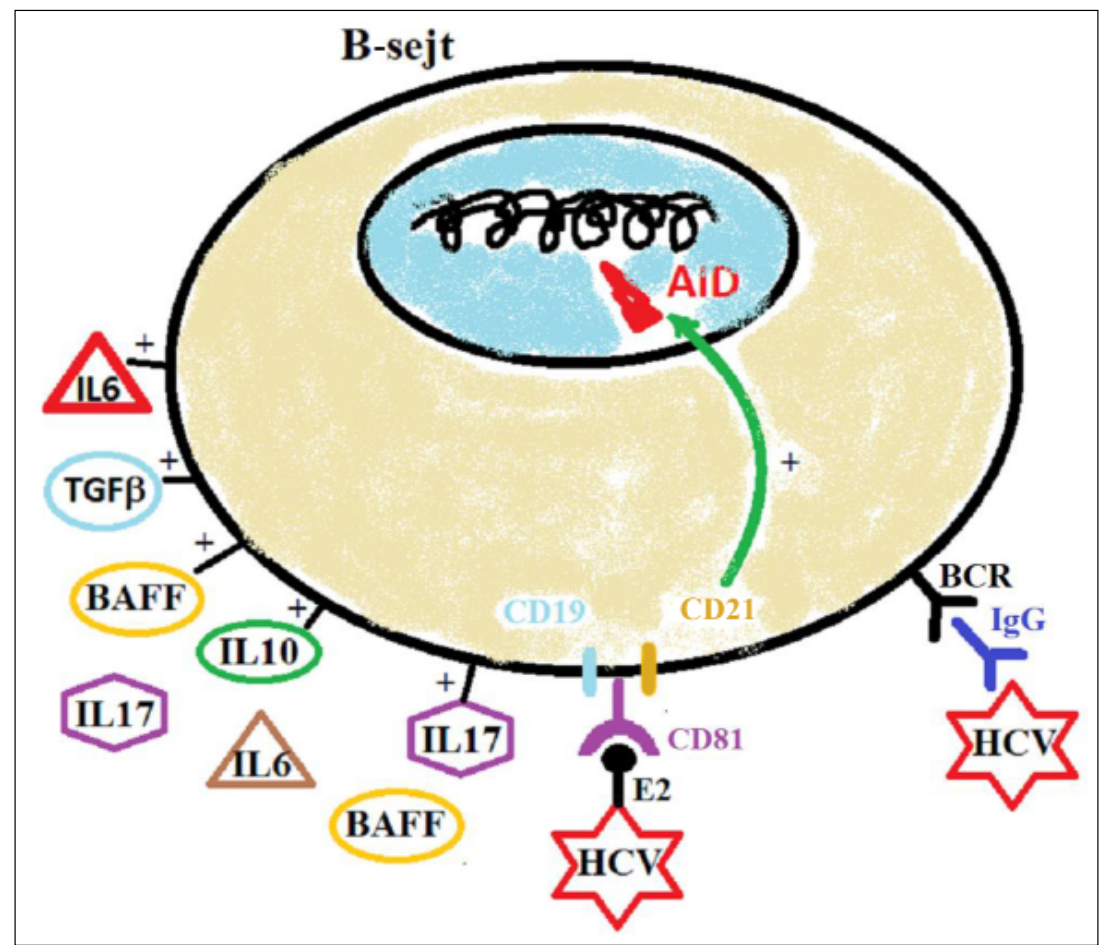

4. ábra. A HCV által okozott indirekt B-sejt-transzformáció modellje. AID: activation-induced cytidine deaminase, IL: interleukin, TGF: tumor growth factor, CD: cluster of differentiation, BAFF: B cell activating factor of tumor necrosis factor family, BCR: B-cell-receptor, Ig: immunglobulin. (Couronné L, et al. [4] közleménye alapján, módosítva, a szerzők engedélyével) 
pedig a B-sejtek számára kritikus túlélési faktor, a BAFF (B-cell activating factor of tumor necrosis factor family) up-regulációjával. Más citokinek és növekedési faktorok is részt vesznek a B-sejt-proliferációban $\mathrm{HCV}$-fertőzésben (4. ábra).

Ugyanakkor a B-sejt-transzformáció krónikus antigénstimuláció nélkül, a $\mathrm{B}$-sejtek direkt infekciója révén is létrejöhet, ahogyan arra a kísérletes állatmodellek utalnak. A hepatitis C-vírus core-proteinjének és nonstrukturális (NS3) proteinjének expressziója indukálja a nitrogén-oxid-szintázt és a reaktív oxigén szabadgyökök képződését, és ezáltal a DNS-mutációk javítása károsodik. A DNS-hibák javítását a checkpoint kináz 2 downregulációjával is akadályozza. Mindezeknek a folyamatoknak szerepük van a daganat kialakulásában is (5. ábra).

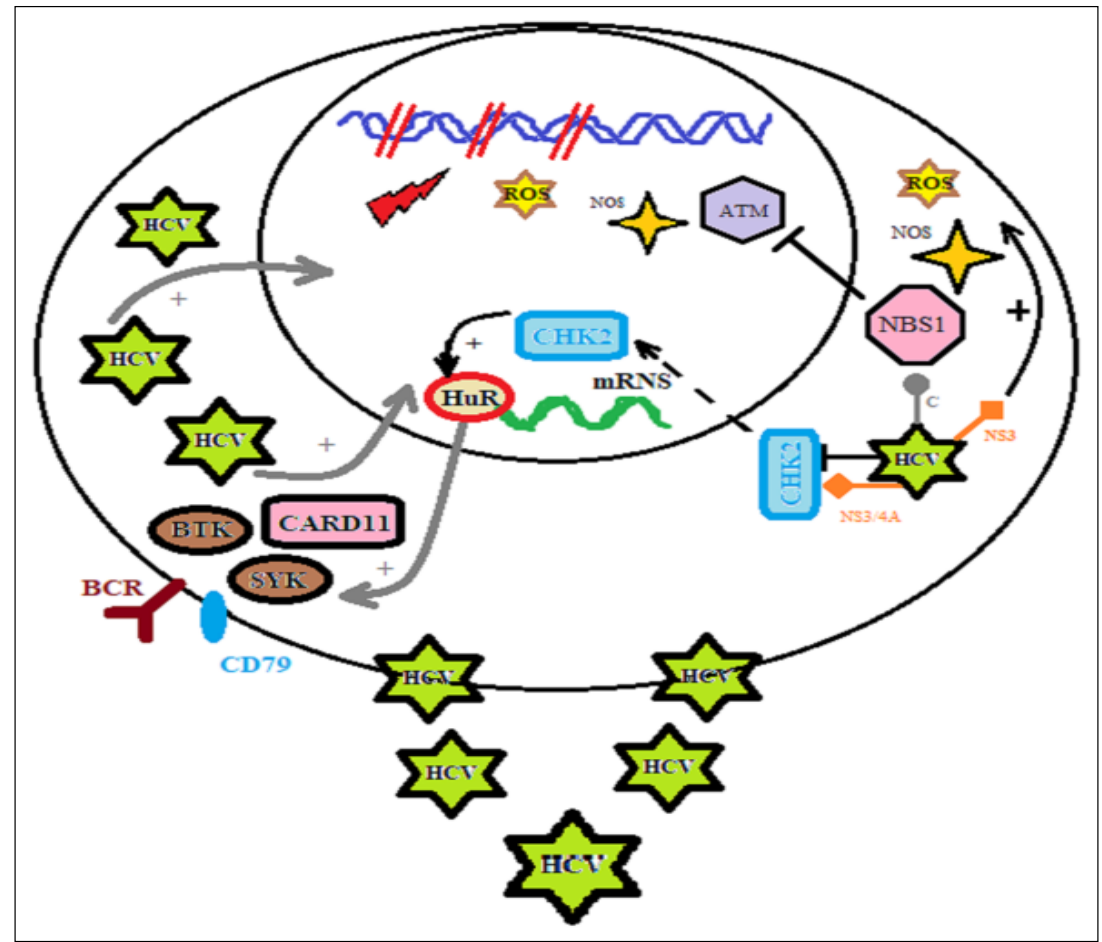

5. ábra. A direkt HCV által mediált onkogén effektusok a B-sejt-transzformációban. ROS: reactive oxigen species, ATM: serin treonin kinase, CHK: check point kinase, NBS1: Nijmegen breakage syndrome, SYK: tyrosine protein kinase. (Couronné L, et al. [4] közleménye alapján, módosítva, a szerzők engedélyével)
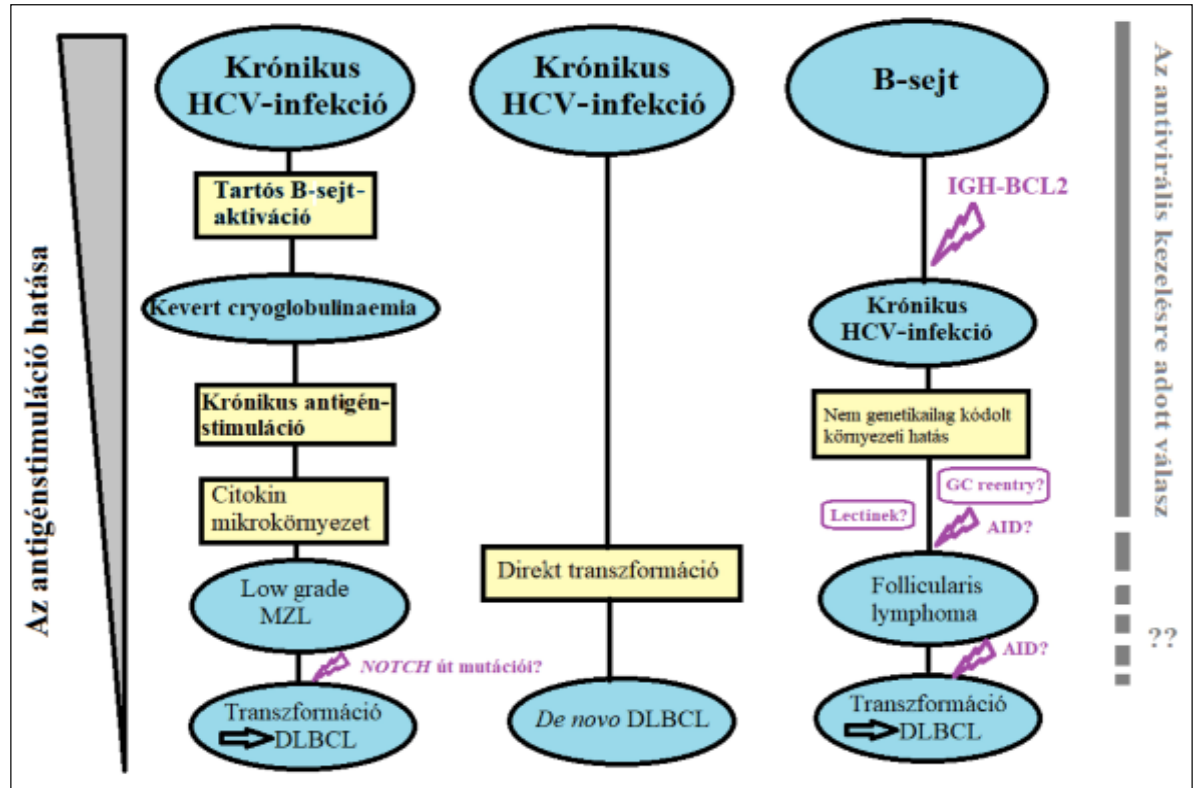

6. ábra. A hepatitis C-vírushoz kötött direkt lymphomagenesis modelljei. DLBCL: diffuse large B cell lymphoma, AID: activation-induced cytidine deaminase, IGH-BCL2: rearrangement in the IgH and BCL2 genes, NOTCH: cell signaling pathway. (Couronné L, et al. [4] közleménye alapján, módosítva, a szerzők engedélyével) 
A mikroRNS-ek közül a miR26b csökkent expresszióját találták HCV-pozitív splenicus marginalis zona lymphomában, amelynek leírták in vitro oncogen szerepét májés tüdődaganatokban, valamint B-sejtes lymphomában. A miR29a, 29b és a miR223 over-expresszióját figyelték meg HCV-hez társuló marginalis zóna lymphomában. Mindezek azt sugallják, hogy a miRNS-ek diszregulációjának szerepe lehet a tumorgenesisben (6. ábra).

\section{A HCV elleni antivirális kezelés és a lymphomaregresszió}

Számos megfigyelés szerint a HCV elleni sikeres antivirális kezelés a HCV-hez társult lymphomák regressziójához vezet. Több tanulmányban leírják, hogy villosus lymphocytákkal járó splenikus lymphomában (SLVL) [39], marginális zóna lymphomában [40], MALT lymphomában [41], Hodgkin-kórban szenvedő HCV-fertőzött betegek jelentős részében a vírus eltűnésével a hematológiai betegség is remisszióba kerül. A lymphoma szubtípusok, az antivirális terápia és egyéb faktorok heterogenitásától függetlenül a komplett hematológiai remisszió szorosan összefüggött a virológiai válasszal. Ez is alátámasztja a HCV szerepét a low-grade lymphomák kialakulásában. $\mathrm{Az}$ agresszív lymphomák esetében más a helyzet. Csupán sporadikusan fordul elő egy-egy eset [42], ahol az antivirális kezelés komplett hematológiai remisszióhoz vezetett.

\section{Betegismertetés}

54 éves férfi beteg esetét ismertetjük példaként, akinek kórelőzményében gyermekkorban mandula-, vakbél-, később több visszérmütét szerepel. Évek óta ismert és kezelt a magasvérnyomás-betegsége.

Jobb bokatáji erysipelas, illetve phlebitis miatti obszerváció során a hozott laboratóriumi leleteiben (2017. 11. 19.) jelentős thrombocytopenia $(44 \mathrm{G} / \mathrm{l})$ és hyperbili- rubinaemia volt látható (total/direct: 70/47 umol/l). Amoxicillin/clavulansav-tartalmú antibiotikumkezelést kapott. Fizikális vizsgálat során máj- és lépmegnagyobbodást észleltünk, lymphadenomegalia nélkül. A hasi CT-vizsgálat jelentősen megnagyobbodott hypodenz lépet mutatott (a lép pólustávolsága $200 \mathrm{~mm}$, hilusi átmerője $77 \mathrm{~mm}$, a középső harmadában $11 \times 33 \mathrm{~mm}$ ). Patológiás megnagyobbodott nyirokcsomó nem látszott.

A laboratóriumi vizsgálatok (2017. 11. 27.) mérsékelten emelkedett obstrukciós enzimértékek (GGT: 69U/1, ALP: $241 \mathrm{U} / \mathrm{l}$ ) és serum bilirubin (seBi: $57 \mathrm{mikromol} / \mathrm{l}$, diBi.: $22 \mathrm{mikromol} / \mathrm{l}$, indirect bilirubin: $35 \mathrm{mikromol} / \mathrm{l}$ ) mellett a máj csökkent szintetikus kapacitására utaltak (cholinesterase: $1981 \mathrm{U} / 1$ ).

Vérképzőszervi rendszerbetegség gyanúja felmerült, a perifériás vérkenetben a mononuclearis lymphoid elemek között szakadozott szélü plazmával rendelkező sejtek látszottak. A fogyás, a gyengeség, az időnként tapasztalt orrvérzés, a fenti hematológiai laboreltérések és a fizikális vizsgálat során észlelt hepatosplenomegalia miatt nonHodgkin-lymphoma gyanúja merült fel. A perifériás véráramlási cytometria eredménye marginális zóna lymphoma mellett szólt (7. ábra).

A pathológiás sejtek CD5-, CD10- és CD103-negatívak voltak, alacsony malignitású B-sejtes lymphoproliferatív megbetegedést jelezve, a crista-biopsia minimális ( $10 \%$ alatti) lymphomás csontvelő-érintettséget mutatott. A Coombs-pozitivitás és a csökkent haptoglobinszint immunhaemolysisre utalt, de szteroidkezelésre a kiderült anti-HCV-pozitivitás miatt nem került sor (8. ábra: crista-biopsia a kezelés elött).

Bár a beteg vérkészítményt korábban nem kapott, intravénás droghasználat nem szerepelt az anamnézisben, az eredmény azt mutatta, hogy korábban találkozott a hepatitis C-vírussal, ezért HCV RNS PCR-vizsgálatot kértünk, ami pozitív eredményt adott. A vírusszám meghatározásán kívül a májbetegség stádiumának megállapítása is fontos, hiszen az mind a betegség várható kimenetelét, mind a kezelési lehetőségeket meghatározza. Az állapotfelmérő hasi UH-vizsgálat során a máj keménységét

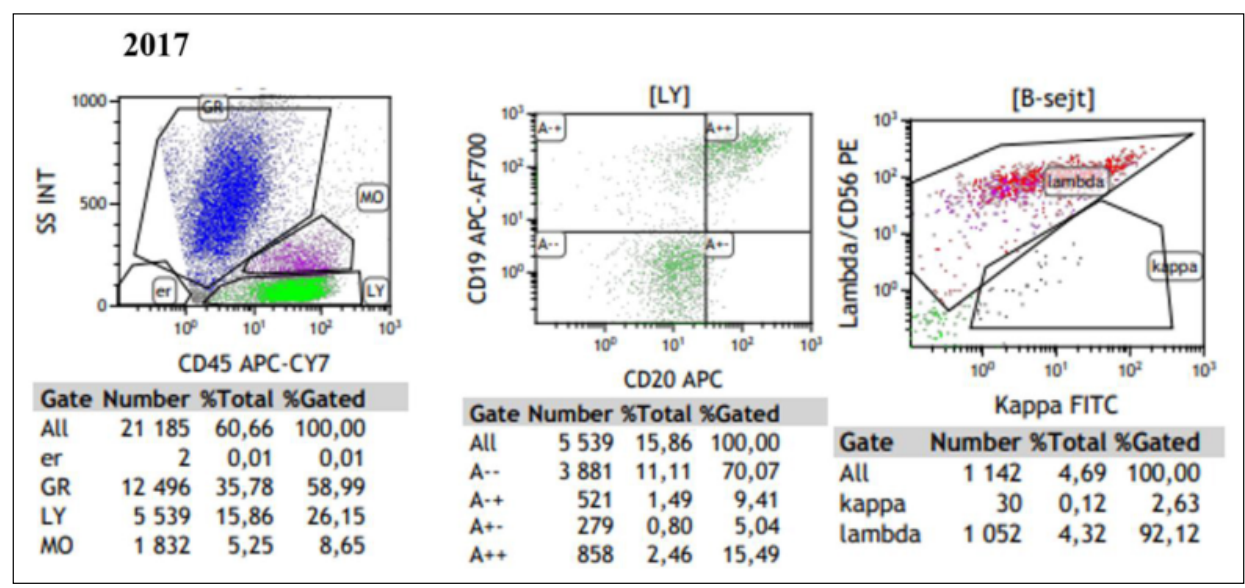

7. ábra. A csontvelő áramlási cytometriás képe az MZL diagnózisakor (2017-ben). 6\% magas CD19, lambda, CD20, közepes CD38-expresszió; CD5-, CD103-, CD11c-, CD10-, CD25-negativitás 


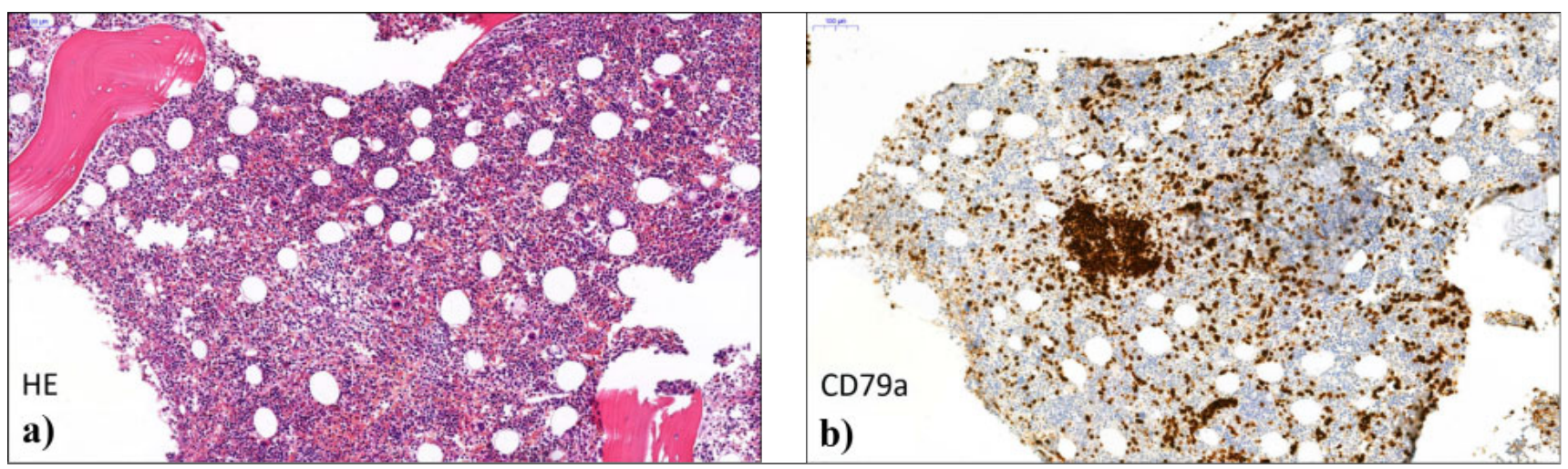

8. ábra. a) A csontvelő biopsziás minta mikroszkópos képe, hematoxylin eosin festés. Megtartott vérképzés, kis nodularis és döntően interstitialis lymphoidokkal, amelyek a b) ábrán láthatóan CD79a-pozitívak

shear-wave elastographiás módszerrel mértük. Az inhomogén szerkezetû, lobulált felszínű, mérsékelten megnagyobbodott máj reflektivitása fokozott volt, benne körülírt eltérés nem látszott. A portalis keringés megtartott volt. A shear wave elastographia során fokozott májkeménységet (26 kPa, IQR/med. 18\%), F4 fokozatú cirrhosist észleltünk (9. ábra).

Hematológiai kezelésnek sürgető indikációja nem állt fenn.

A hepatitis C-pozitív betegek adatait összegző hepatitisregiszterbe a beteg adatait feltöltöttük. Az antivirális kezelések elbírálásánál a májbetegség stádiumán és a beteg általános állapotán kívül a kezelendő lymphoma ténye is szerepet játszik, a kezelés megkezdését sürgeti, hiszen az antivirális kezeléssel a hematológiai betegség javulása is várható.

A PCR- és genotípusvizsgálatok 2,09 E5 IU/ml vírus copiaszámot és a Magyarországon leggyakoribb 1b genotípust igazolták. Az előrehaladott, Child-Pugh B stádiumú májcirrhosis miatt az ebben a stádiumban is adható, $1 \mathrm{~b}$ genotípusban igen jó hatásfokkal alkalmazható sofosbuvir/ledipasvir-tartalmú direkt antivirális kezelést kezdtünk, ribavirinnel kiegészítve. A ribavirin elvben okozhat hemolízist, ami már a kórelőzményben is előfordult. Az enyhe fokú transzfúziót még nem igénylő anaemiára való tekintettel adását fokozott óvatossággal kezdtük. A vérképét a szokásosnál gyakrabban ellenőriztük, és a haemolysisre utaló laboradatoknak megfelelően a ribavirinadagját csökkentettük, majd elhagytuk.

Az antivirális kezelés alatt új panasz nem jelentkezett. Testsúlya gyarapodott. Éjszakai izzadás, fejfájás, szédülés, mellkasi panasz nem volt. Az icterus továbbra is megmaradt. Laboradatai közül kiemelendő az enyhe fokú anaemia, a mérsékelten emelkedett $\mathrm{LDH}$, az indirekt bilirubinaemia és a csökkent haptoglobin $(0 \mathrm{~g} / \mathrm{l})$.

A kezelés közben kismértékü, fizikai terhelésre fokozódó szimmetrikus alsó végtagi, ujjbenyomatot megtartó oedema jelentkezett, mely kis dózisú diuretikus terápiára jól reagált. Nehézlégzés, mellkasi panasz nem volt. Általános állapota javult, fáradékonysága mérséklődött.

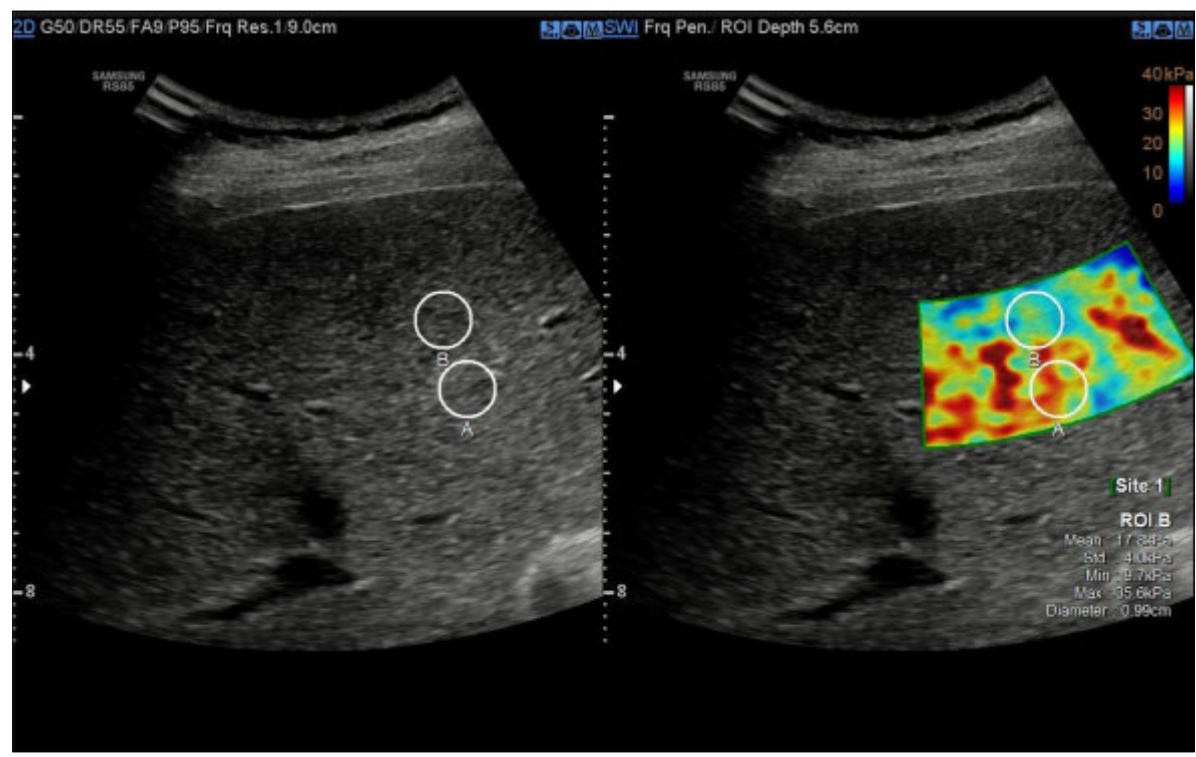

9. ábra. A máj elastographiás vizsgálata. A máj keménységmérésének eredménye látható. A fokozott liver stiffness érték a májkötőszövetes átépülésére utal 


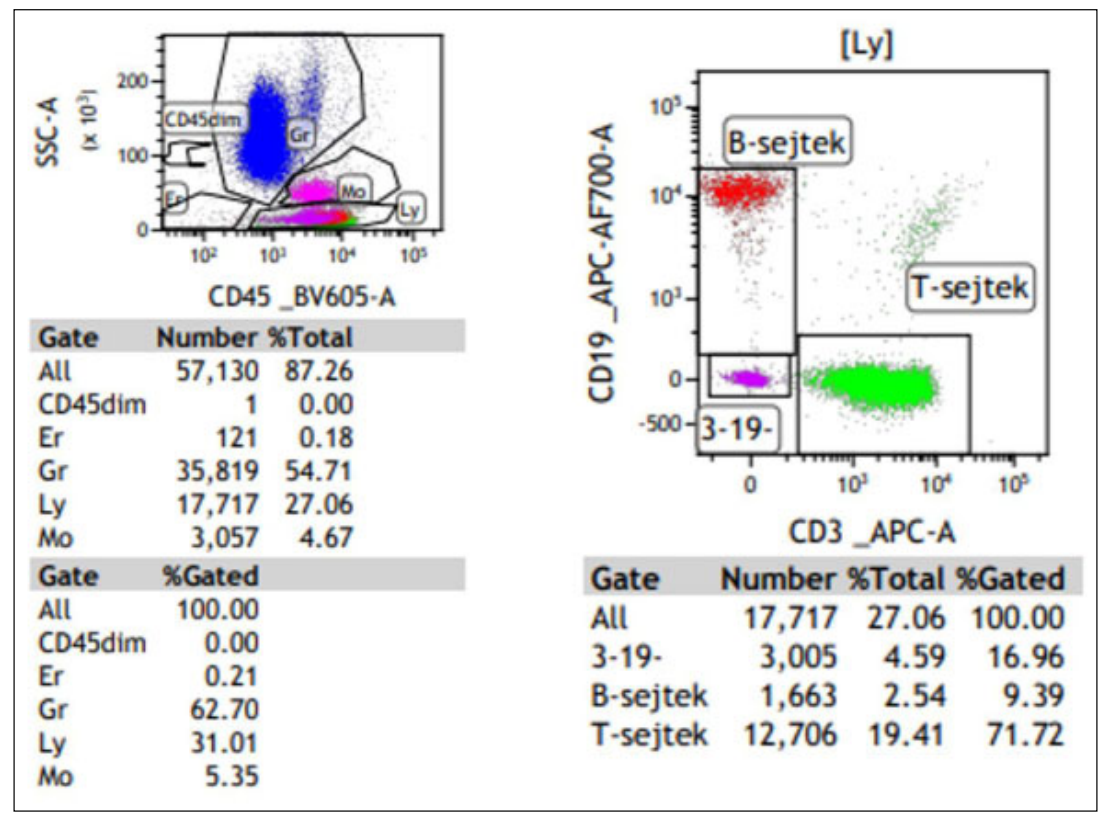

10. ábra. Perifériás véráramlási cytometria az antiviralis kezelést követően. (3\%, közepes $\lambda$ könnyü lánc expressziójú, monoclonalis, kóros B-sejt. A sejtek fenotípusa: CD45br, CD19poz, CD5neg, CD10neg, $\lambda$ poz) A kóros klón még jelen van, de a lymphocyták abszolút száma megfeleződött

A 10. ábrán a perifériásvér-áramlás cytometriás képe látható az antivirális kezelést követően. A normalizálódott vérsejtszámok ismeretében újabb csontvelővizsgálatnak már nem volt javallata. A lymphocyták abszolút száma a perifériás vérben az antivirális kezelést követően a felére (a kiindulási 5, 77 G/l-ről 2,31 G/l-re) csökkent, normál tartományba került.

A 12 hetes antivirális kezelés végére panasza nem volt, erőnléte javult. HCV PCR-negatívvá vált, tehát virológiai szempontból gyógyultnak tekinthető. A társuló immunhaemolysis mértéke csökkent. LDH-értéke az antivirális kezelés befejeztével fokozatosan csökkent. LDH-kezelés előtt $294 \mathrm{U} / 1$, ribavirin mellett $359 \mathrm{U} / 1$, a ribavirint elhagyva és az antivirális kezelést folytatva a kezelés második hónapjában már $251 \mathrm{U} / 1$, a kezelést követően pedig 224, majd $159 \mathrm{U} / \mathrm{l}$. A serum bilirubin/direct bilirubin a 70/47-ről átmeneti növekedés - 138/37-ig - később 49/18, majd 23/15 umol/l-re csökkent.

Lymphoma specifikus kezelése jelenleg nem indokolt, a beteg további követése szükséges, és progresszió esetén rituximab monoterápia jön szóba.

Bár az irodalomból ismert, hogy a HCV eradikációját követően a B-sejtes non-Hodgkin-lymphoma is remisszióba kerülhet, esetünkben az eddig eltelt időszakban ezt nem észleltük, igaz, hogy progressziót sem.

\section{Megbeszélés}

$\mathrm{Az}$ általunk ismertetett eset egy splenicus marginalis zona lymphomában szenvedő hepatitis C-vírus-pozitív beteg tartós virológiai gyógyulását mutatja. $\mathrm{E}$ beteg példáján is jól látható, hogy a direkt antivirális kezelés a B-sejtes marginális zóna lymphomában is jól tolerálhatónak bizo- nyult, és virológiai szempontból hatékony volt. A vírusnak a direkt lymphomagenesisben játszott szerepe azt sugallja, hogy a tartós vírusmentességtől a hematológiai betegség remissziója is remélhető. Bár esetünkben - az egyes irodalmi adatok [43-45] alapján várt - teljes hematológiai válasz még nem következett be, a perifériás vérkép és flow cytometria szerint a hematológiai adatok is valamelyest javultak. A lép mérete ugyan nem csökkent, de ennek hátterében több ok is állhat. Egyrészt a korábban már kezdődő dekompenzációs tüneteket is okozó májcirrhosis, a következményes portalis hypertensio, másrészt maga a lymphoma. A hosszabb ideje fennálló congestiv eredetű splenomegalia az esetek többségében várhatóan már nem fejlődik vissza. Bár a májcirrhosishoz vezető noxát, a hepatitis C-vírust sikerült eliminálni, s ezzel a már kialakult májzsugor progressziója megállítható, jó egyensúlyi állapot akár évekig fennállhat, maga a krónikus májbetegség nem gyógyul meg, a rendszeres laboratóriumi és képalkotó kontrollvizsgálatok fontosak. A nemzetközi és hazai irodalmi adatok alapján a direkt antivirális kezelésben nem gyakoribb a gócos májlaesiók előfordulása, bár fontos megemlíteni, hogy ezekkel az antivirális szerekkel súlyosabb, előrehaladottabb állapotú, mindezek miatt a szövődmények szempontjából fokozott kockázattal bíró betegeket kezelünk, és a kötőszövetesen átépült májban a regenerációs göbökben bármikor kialakulhat dysplasiás nodulus, malignus laesio. Emiatt ezeket a betegeket szükséges legalább hathavonta ultrahanggal is követni, illetve soron kívül is, ha fogyás vagy egyéb alarmírozó tünetet észlelünk.

Párhuzamot vonva a Helicobacter pylori okozta krónikus antigénprezentáció talaján kialakult MALT lymphoma esetével, itt is elképzelhető, hogy a többféle mechanizmus 
által indukált malignus betegség kialakulása egy bizonyos stádiumon túl már függetlenné válik az eredeti folyamatot beindító noxától. A felnőttkori non-Hodgkin-lymphomák előfordulását és azok kezelését mutatta be Kollár Balázs munkacsoportja 2009-ben [46] két magyarországi centrum adatai alapján. A Debreceni Orvostudományi Egyetemen évtizedek óta múködő lymphomacentrum munkatársai számos közleményben mutatták be nagyszámú non-Hodgkin-lymphomás betegben a társuló autoimmun kórképek előfordulását [47], a hepatitis B-, C- és G-vírusinfekciók gyakoriságát, illetve azok szerepét a lymphomák kialakulásában [48].

Klinikánk hematológiai osztályán is számos lymphomás beteg kezelése történt az elmúlt évtizedekben, akik között több HBV- és HCV-pozitív beteg volt. Korábban interferonalapú antivirális kezelést kaptak a HCV-pozitív betegek. Ismert az ilyen kezelés antiproliferatív hatása, s nehéz elkülöníteni, hogy mi írható az interferon és mi a víruselimináció javára. Bár az esetek nagy többségében a hematológiai regresszió már a vírus eliminációjával párhuzamosan várható, ugyanakkor néhány esetben leírták, hogy például a cryoglobulin eltűnése néhány hónappal, akár egy évvel is később következik be.

Mindezeket figyelembe véve, az interferonmentes antivirális kezelés elsődleges kuratív gyógymódot nyújthat a HCV-hez társuló indolens lymphomák esetében, vagyis az indolens lymphomák terápiájának tárházában ez egy valódi kemoterápiamentes kezelés lehet [49]. Az utóbbi évtizedekben számos tanulmány azt igazolta, hogy az interferonalapú anti-HCV-kezelésre a $\mathrm{HCV}$-asszociált indolens B-sejtes lymphomák közel 75\%-a került hematológiai remisszióba, szignifikánsan jobb túlélést mutatva. A direkt antivirális szerekkel ugyan még relatíve kevés adat áll rendelkezésre, ezek az adatok is nagyon biztatóak. Persico és mtsai húsz HCV $1 \mathrm{~b}$ genotípussal fertőzött, DLBCL-ben szenvedő beteg kezelése során azt találták, hogy a kemoterápiával együtt alkalmazott direkt antivirális kezelés biztonságos volt, és hatékonynak bizonyult az agresszív lymphomák kezelésében, hematológiai remissziót eredményezve [50]. Hasonlóan jó eredményekről számolt be egy egyiptomi munkacsoport, amely húsz 4-es genotípusban szenvedő HCV-pozitív leukémiás, illetve lymphomás gyermek esetét közölte. Sofosbuvir/daclatasvir-kezelést alkalmazva nem volt relapsus sem virológiai, sem hematológiai szempontból [51]. $\mathrm{Az}$ új, interferonmentes kezelések biztonságosak, gyorsak, hatékonyak, és mind a HCV-vel összefüggő malignus betegségek, mind a HCV-infekció egyéb késői szövődményeinek kivédésében jótékony hatásúak [50].

A HCV és a malignus lymphomák kapcsolatának összetettségét jelzi, illetve az agresszív lymphomák többlépcsős patogezenisének megfelel, hogy a víruseradikáció önmaga általában nem vezet az agresszív lymphoma gyógyulásához. Ugyanakkor a lymphoma immunokemoterápiás kezelését antivirális védelemben kell végezni [52].

Noha betegünk esetében a hepatitis C-vírus sikeres kezelését követően az MZL nem került remisszióba, de a beteg tünetmentessé vált, és a következő 18 hónapban nem szorult hematológiai kezelésre. Munkánkkal újra felhívjuk a figyelmet a HCV- és HBV-szürés fontosságára a lymphoid malignitásban szenvedő betegek ellátása kapcsán. Az antivirális kezelés javítja a májbetegség és sok esetben a lymphoma prognózisát is. Fontos a hepatológiai és hematológiai centrumok együttmüködése, ami hazánkban több helyen megvalósul, de még van tennivaló ezen a téren.

Nyilatkozat: Ezúton nyilatkozom arról, hogy a közlemény más folyóiratban korábban nem jelent meg, és máshova beküldésre nem került. A szerzői útmutatót elolvastam. Érdekeltségek: A szerzőknek nincsenek érdekeltségeik. Anyagi támogatás: A munka anyagi támogatásban nem részesült.

Szerzői munkamegosztás: F.A. - az irodalmi adatok öszszegzése, a beteg dokumentációjának feldolgozása, a kezelés értékelése; T.I. - hematológiai kezelés; N.D. - a HCV elleni kezelés irodalmi adatainak feldolgozása; Cs.B., R.H., M.A. - a beteg perifériás kenetének és csontvelőbiopsziás mintájának vizsgálata, leletezése; K.N.P. - a hasi UH és a máj elastographiás vizsgálatának elvégzése, értékelése; A.M. - a beteg direkt antivirális kezelése a terápia kezdetén; T.T. - a beteg hepatológiai kezelésének folytatása; Sz.F. - a beteg hepatológiai kezelése és az irodalmi jegyzék áttekintése, javítása; D.J. - a beteg hematológiai kezelése, gondozása, a hematológiai irodalmi adatok át ${ }^{-}$ tekintése, javítása.

Köszönetnyilvánítás: Dr. Rajnai Hajnalkának a flow cytometria és crista-biopsia képanyagáért.

\section{Irodalom}

[1] Fattovich G, Stroffolini T, Zagni I, et al. Hepatocellular carcinoma in cirrhosis: incidence and risk factors. Gastroenterology 2004; 127: S35-S50.

[2] Chen SL, Morgan TR. The natural history of hepatitis $\mathrm{C}$ virus (HCV) infection. Int J Med Sci. 2006; 3: 47-52.

[3] Pár A, Pár G. Immune response and oxidative stress in hepatitis C virus infection. [Immunválasz és oxidatív stressz hepatitis Cvírus-infekcióban] Orv Hetil. 2015; 156: 1898-1903. [Hungarian]

[4] Couronné L, Bachy E, Roulland S, et al. From hepatitis C virus infection to B-cell lymphoma. Ann Oncol. 2017; 29: 92-100.

[5] Szabo E, Lotz G, Paska C et al. Viral hepatitis: new data on hepatitis C infection. Pathology oncology research: POR. 2003; 9: 215221.

[6] Lotz G, Kiss A, Kaposi Novák P, et al. Hepatitis viruses and hepatocarcinogenesis. J Physiol-Paris 2001; 95: 417-422.

[7] Talamini R, Montella M, Crovatto M et al. Non-Hodgkin's lymphoma and hepatitis $\mathrm{C}$ virus: a case-control study from northern and southern Italy. Int J Cancer 2004; 110: 380-385.

[8] Zuckerman E, Zuckerman T, Levine AM, et al. Hepatitis C virus in patients with B-cell non-Hodgkin lymphoma. Ann Intern Med. 1997; 127: 423-428.

[9] De Sanjose S, Benavente Y, Vajdic CM. Hepatitis C and non-Hodgkin lymphoma among 4784 cases and 6269 controls from the International Lymphoma Epidemiology Consortium. Clin Gastroenterol Hepatol. 2008; 6: 451-458. 
[10] Giordano TP, Henderson L, Landgren O, et al. Risk of non-Hodgkin lymphoma and lymphoproliferative precursor diseases in US veterans with hepatitis C virus. JAMA 2007; 297: 2010-2017.

[11] Nieters A, Kallinowski B, Brenner P et al. Hepatiti C and risk of lymphoma: results of the European multicenter case-control study EPILYMPH. Gastroenterology 2006; 131: 1879-1886.

[12] Pozzato G, Mazzaro C, Dal Maso L, et al. Hepatitis C virus and non-Hodgkin lymphomas: meta-analysis of epidemiology data and therapy options. World J Hepatol. 2016; 8: 107-116.

[13] World Health Organization. Global Hepatitis Report 2017. https://apps.who.int/iris/bitstream/handle/10665/255016/ 9789241565455-eng.pdf

[14] De Sanjose S, Benavente Y, Vajdic CM. Hepatitis C and non-Hodgkin lymphoma among 4784 cases and 6269 controls from the International Lymphoma epidemiology Consortium. Clin Gastroenterol Hepatol. 2008; 6: 451-458.

[15] Barna TK, Ozsvár Zs, Szendrényi V, et al. Hepatitis C virus antibody in the serum of blood donors. [Hepatitis C-vírus ellenanyag előfordulása véradók szérumában.] Orv Hetil. 1996; 137(10): $507-$ 511. [Hungarian]

[16] National Center for Epidemilogy. Prevalences of HIV and HCV infections in Hungary related to intravenous drug abuse in 2014 [Országos Epidemiológiai Központ: Az intravénás kábítószerhasználattal összefüggő hazai HIV-, illetve HCV-prevalencia 2014ben.] EPINFO 2015; 22(18): 189-194. [Hungarian]

[17] Hunyady B, Gerlei Zs, Gervain J, et al. Screening, diagnosis, treatment, and follow up of hepatitis $\mathrm{C}$ virus related liver disease. $\mathrm{Na}-$ tional consensus guideline in Hungary from 26 March 2018. [Hepatitis C-vírus fertőzés szűrése, diagnosztikája, antivirális terápiája, kezelés utáni gondozása. Magyar konszenzusajánlás. Érvényes: 2018. március 26-tól]. Centr Eur J Gastroenterol Hepatol. 2018; 4: 53-68. [Hungarian)

[18] Chevaliez S, Pawlotsky JM. HCV Genome and Life Cycle. In: Tan SL (ed.) Hepatitis C viruses: Genoms and Molecular Biology. Horizon Bioscience, Norfolk (UK), 2006.

[19] Schaff Zs, Gógl A, Dóra R, et al. The pathology of hepatitis C. [A hepatitis C patológiája.] Orv Hetil. 2015, 156: 836-839. [Hungarian]

[20] Abdel-Hakeem MS, Shoukry NH. Protective immunity against hepatitis C: many shades of gray. Front Immunol. 2014; 5: 274.

[21] Pawlotsky JM. NS5A inhibitors in the treatment of hepatitis C. J Hepatol. 2013; 59: 375-382.

[22] World Health Organization. Global health sector strategy on vira hepatitis 2016-2021. https://apps.who.int/iris/bitstream/handle/ 10665/246177/WHO-HIV-2016.06-eng.pdf ?sequence $=1$

[23] Gervain J, Simon G Jr, Papp I, et al. Analysing the type and subtype of hepatitis virus $\mathrm{C}$ of chronic viral hepatitis patients in Hungary. [A magyarországi krónikus C vírushepatitises betegek vírustípus- és szubtípus meghatározása.] Orv Hetil. 2001; 142(25): 1315-1319. [Hungarian]

[24] Manns MP, Foster GR, Rockstroh JK et al. The way forward in HCV treatment - finding the right path. Nat Rev Drug Discov. 2007; 6: 991-1000.

[25] European Association for Study of the Liver. EASL recommendations on treatment of hepatitis C 2016. J Hepatol. 2017; 66: 153194.

[26] Liverpool HEP Interactions: https://www.hep-druginteractions. org/

[27] Poveda E, Wayles DL, Mena A, et al. Update on hepatitis C virus resistance to direct-acting antiviral agents. Antiviral Res. 2014; 108: 181-191.

[28] Dvory-Sobol H, Wyles D, Ouyang W, et al. Long-term persistence of HCV NS5A variants after treatment with NS5A inhibitor ledipasvir. J Hepatol. 2015; 62: S221.

[29] Gumber SC, Chopra S. Hepatitis C. A multifaceted disease. Review of extrahepatic manifestations. Ann Intern Med. 1995; 123: 615.
[30] Pawlotsky JM, Ben Yahia M, Andre C, et al. Immunologocal disorders in $\mathrm{C}$ virus chronic active hepatitis: a prospective case-control study. Hepatology 1994; 19: 841.

[31] Iqbal T, Mahale P, Turturro F et al. Prevalence and association of hepatitis $\mathrm{C}$ virus infection with different types of lymphoma. Int $\mathrm{J}$ Cancer 2016; 138: 1035-1037.

[32] Anderson LA, Pfeiffer R, Warren JL, et al. Hematopoietic malignancies associated with viral and alcoholic hepatitis. Cancer Epidem Biomarkers Prev. 2008; 17: 3069-3075.

[33] Arcaini L, Burcheri S, Rossi A, et al. Prevalence of HCV infection in nongastric marginal zone B-cell lymphoma of MALT. Ann Oncol. 2007; 18: 346-350.

[34] Besson C, Canioni D, Lepage E, et al. Characteristics and outcome of diffuse large $\mathrm{B}$-cell lymphoma in hepatitis $\mathrm{C}$ virus-positive patients in LNH 93 and LNH 98 Groupe d'Etude des Lymphomes de l'Adulte Programs. J Clin Oncol. 2006; 24: 953-960.

[35] Sulyok M, Makara M, Újhelyi E. Non-Hodgkin lymphoma and hepatitis C: Where we are and what next? Pathol Oncol Res. 2015; 21: $1-7$.

[36] Suarez F, Lortholary O, Hermine O, et al. Infection-associated lymphomas derived from marginal zone B cells: a model of antigen-driven lymphoproliferation. Blood 2006; 107: 3034-3044.

[37] Ramos-Casals M, Stone JH, Cid MC, et al. The cryoglobulinaemias. Lancet 2012; 379: 348-360.

[38] Bachy E, Besson C, Suarez F, et al. Hepatitis C virus infection and lymphoma. Mediterr J Hematol Infect Dis. 2010; 2(1): e2010004.

[39] Hermine O, Lefrere F, Bronowicki JP, et al. Regression of splenic lymphoma with villous lymphocytes after treatment of hepatitis $\mathrm{C}$ virus infection. N Engl J Med. 2002; 347: 89-94.

[40] Kelaidi C, Rollot F, Park S, et al. Response to antiviral treatment in hepatitis $\mathrm{C}$ virus-associated marginal zone lymphomas. Leukemia 2004; 18: 1711-1716.

[41] Tursi A, Brandimarte G, Torello M, et al. Disappearance of gastric mucosa-associated lymphoid tissue in hepatitis $\mathrm{C}$ virus-positive patients after anti-hepatitis C viral therapy. J Clin Gastroenterol. 2004; 38: 360-363.

[42] Iannitto E, Ammatuna E, Tripodo C, et al. Long-lasting remission of primary hepatic lymphoma and hepatitis $\mathrm{C}$ virus infection achieved by the alpha-interferon treatment. Hematol J Off J Eur Haematol Assoc/EHA 2004; 5: 530-533.

[43] Patriarca F, Silvestri F, Fanin R, et al. Regression of lymphoproliferative disorder after treatment for hepatitis $\mathrm{C}$ virus infection in a patient with partal trisomy $3, \mathrm{Bcl}-2$ overexpression, and type II cryoglobulinaemia. Blood 2002; 99: 2259-2261.

[44] Zuckerman E, Zuckerman T, Sahar D, et al. The effect of antiviral therapy on $\mathrm{t}(14 ; 18)$ translocation and immunglobulin gene rearrangement in patients with chronic hepatitis $\mathrm{C}$ virus infection. Blood 2001; 97: 1555-1559.

[45] Arcaini L, Vallisa D, Rattotti S, et al. Antiviral treatment in patients with indolent B-cell lymphomas associated with HCV infection? A study of the Fondazione Italiana Linfomi. Ann Oncol. 2014; 25: 1404-1410.

[46] Kollár B, Rajnics P, Hunyady B, et al. Primary gastrointestinal non-Hodgkin's lymphoma in two Hungarian regions. [Primer gastrointestinalis non-Hodgkin-lymphoma két magyarországi régió beteganyaga alapján.] Orvosi Hetil. 2009; 150: 1649-1653. ISSN 0030-6002. [Hungarian]

[47] Váróczy L, Gergely L, Zeher M, et al. Malignant lymphoma-associated autoimmune diseases - a descriptive epidemiological study. Rheumat Intern. 2002; 22: 233-237.

[48] Keresztes K, Takács M, Horányi M, et al. HCV and HGV infection in Hodgkin's disease. Pathol Oncol Res. 2003; 9(4): 222-225. Epub: 2003. Dec. 22.

[49] Merli M, Carli G, Arcaini L, et al. Antiviral therapy of hepatitis C as curative treatment of indolent B-cell lymphoma. World J Gastroenterol. 2016; 22: 8447-8458.

[50] Persico M, Aglitti A, Caruso R, et al. Efficacy and safety of new direct antiviral agents in hepatitis $\mathrm{C}$ virus-infected patients with 
diffuse large B-cell non-Hodgkin's lymphoma. Hepatology 2018; 67(1): 48-55. DOI: 10.1002/hep.29364. Epub: 2017. Nov. 24.

[51] El-Shabrawi MH, Sherief LM, Yakoot M, et al. Effects of dual sofosbuvir/daclatasvir therapy on, chronic hepatitis $\mathrm{C}$ infected, survivors of childhood malignancy. World J Clin Cases 2019; 7(16) 2247-2255. DOI: 10.12998/wjcc.v7.i16.2247.
[52] Hussein K, Fouad A, Rasha H. Hepatitis C virus and non-Hodgkin's lymphomas: A minireview. J Adv Res. 2017; 8(2): 131-137. Published online 2016. Dec 12. DOI: 10.1016/j.jare.2016.11.005.

A cikk a Creative Commons Attribution 4.0 International License (https://creativecommons.org/licenses/by/4.0/) feltételei szerint publikált Open Access közlemény, melynek szellemében a cikk bármilyen médiumban szabadon felhasználható, megosztható és újraközölhető, feltéve, hogy az eredeti szerző és a közlés helye, illetve a CC License linkje és az esetlegesen végrehajtott módosítások feltüntetésre kerülnek. (SID_1) 